Saudi Journal of Business and Management Studies Abbreviated Key Title: Saudi J Bus Manag Stud ISSN 2415-6663 (Print) |ISSN 2415-6671 (Online) Scholars Middle East Publishers, Dubai, United Arab Emirates Journal homepage: https://saudijournals.com

\title{
The Effect of Electronic Word of Mouth and Sales Promotion on Brand Switching with Brand Image as an Intervening Variable at Erha Beauty Clinic in Samarinda City
}

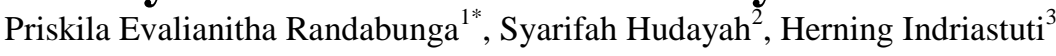 \\ ${ }^{1,2,3}$ Faculty of Economics and Business, Mulawarman University
}

\begin{abstract}
DOI: $10.36348 /$ sjbms.2021.v06i04.001
| Received: 06.03.2021 | Accepted: 27.03.2021 | Published: 02.04.2021

*Corresponding author: Priskila Evalianitha Randabunga

\section{Abstract}

The purpose of this study was to determine the effect of electronic word of mouth and sales promotion on brand switching with brand image as an intervening variable at the ERHA Beauty Clinic in Samarinda City. The study was conducted using 115 respondents. The analysis tool used is SmartPLS 3. Data analysis is carried out by assessing the outer model or measurement model and assessing the inner model or structural model. The results showed that electronic word of mouth and sales promotion partially had a significant positive effect on brand switching, and electronic word of mouth and sales promotion had a significant positive effect on brand switching through the brand image variable as an intervening variable.

Keywords: Electronic Word of Mouth, Sales Promotion, Brand Switching, Brand Image.

Copyright (0) 2021 The Author(s): This is an open-access article distributed under the terms of the Creative Commons Attribution 4.0 International License (CC BY-NC 4.0) which permits unrestricted use, distribution, and reproduction in any medium for non-commercial use provided the original author and source are credited.
\end{abstract}

\section{INTRODUCTION}

Competition between products in the oligopoly market requires business actors to make various efforts to retain their customers and grab customers from other products. In companies engaged in services, competition between products is a complicated matter because the services provided are directly felt by consumers and create a perception. Most of the consumers of beauty clinic service companies are women, but there are also many men who use beauty clinics to do their facial and skin care. The number of beauty clinics makes consumers free to choose the best one that suits their wishes. Brand switching or brand switching is a consumer behavior that has the freedom to choose products or services according to their perceptions. Brand switching as the extent to which consumers switch brands based on their perceptions of the product and service provider [1].

People who are active and interact on social media have the freedom to comment positively or negatively on a product or service. This phenomenon must be faced by beauty clinic business actors and becomes a challenge in the competition to win the hearts of consumers so that they do not change brands or what is known as brand switching. Brand switching can be influenced, one of which is electronic word of mouth (eWOM) [2]. eWOM is widely considered to be one of the most influential factors influencing consumer behavior [3]. This form of communication has become very important with the emergence of online platforms which make it one of the most influential sources of information on the web [4]. ERHA beauty clinic builds communication through social media with the hope that consumers will get positive and reliable information.

Apart from eWOM, to attract customers, beauty clinics usually carry out sales promotion activities. According to [5] sales promotion is a marketing activity other than personal selling, advertising and publicity that stimulates consumer buying and dealer effectiveness. Various promotional efforts have been made by beauty businesses to retain and attract consumers. One of them is sales promotion. ERHA Clinic in Samarinda City conducts sales promotions even though it is not carried out regularly in 
Priskila Evalianitha Randabunga et al., Saudi J Bus Manag Stud, Apr, 2021; 6(4): 102-113

order to maintain its image as a top beauty clinic by not being too indulgent in sales promotion tools.

Apart from sales promotion, ERHA clinic also builds brand image which is one of the company's assets. Brand image is a consumer's perception formed in their memory which is reflected in brand association [6]. ERHA Clinic, which is a national scale clinic, must really maintain the brand image in each of its clinics that are spread across major cities in Indonesia. consumers will be more likely to choose products or services that have a good brand image. A decrease in brand image in one clinic will have a negative impact on all ERHA clinics. Therefore, in this study the authors include brand image as an intervening variable.

Based on the description above, the researchers are interested in conducting research with electronic word of mouth (eWOM) research variables, sales promotion, brand switching, and brand image.

\section{LITERATURE REVIEW Brand Switching}

In general, subjective attitudes and norms play an important role in transitional behavior [7]. According to [8] brand switching is a process where consumers start using other brands of products or services and leave routine brands of similar products that they frequently use. Therefore, brand switching is a complex and complex challenge for the continuous development of service providers.

Brand switching occurs when brand loyalty is affected. Brand loyalty is nothing but when a customer stays with a certain brand for years and he will not use any other brand besides their brand [9].

It can be concluded that brand switching is a psychological behavior of consumers who switch from one brand to another based on their perception of the product or service that leads to the purchase of a product or service. Dimensions that affect brand switching are price, level of customer satisfaction, service quality, inconvenience, low service, ease of switching.

\section{Electronic Word of Mouth}

The new form of online WOM communication is currently known as electronic word of mouth (eWOM) [10]. Consumers perceive eWOM as a much more reliable medium than traditional media [11]. eWOM consists of one useful source of information anonymously which facilitates consumers to peer experience, knowledge acquisition, and opinion through various online platforms, discussion forums, blogs, and review websites [3]. EWOM communication is widely recognized as a non-commercial and reliable source of information that has a major influence on consumer purchasing attitudes and behavior [12].
From the above definition, it can be concluded that eWOM is either positive or negative statements from consumers who are believed to be trusted by using social media on the internet network. The dimensions that affect eWOM are: Intensity, is the number of opinions or comments written by consumers on social media, Content, is the content of information from social networking sites related to products or services, Positive opinions, are positive comments from consumers about products, services, and brand; and Negative opinions, are negative comments from consumers regarding products, services and brands.

\section{Sales Promotion}

Sales promotion is a vital tool that helps marketers to achieve sales targets and increase company profits which emphasizes on stronger short-term stimuli and motivational strategies to improve purchasing behavior and also encourages consumers to switch from competing brands [13]. Sales promotion as an important component of the marketing mix has been widely used as a major incentive tool to attract consumers to stores and increase short-term sales volume [14]. The consumer market will change with changing lifestyles and constantly present different promotional tactics, such as gifts for a pair of sports shoes, cash returns, discounts and coupons, gifts, and cash or gifts for returned certificates [15]. The power of sales promotion tools is associated with consumer perception, in which consumers evaluate sales promotions as opportunities to benefit [16].

The conclusion from the above definitions is that Sales Promotion is part of a Promotion Mix that uses consumer motivation strategies to make purchases for the short term with various techniques.

According to [17], sales promotion has several tools that can be used, namely: Coupons, Cash Refund Offers (rebates), Price Packs (cents-off deals, Premiums (gifts); Frequency Programs; and Free Trials.

\section{Brand Image}

According to [18] brand image is a series of descriptions about the association and consumer beliefs in a particular brand. A good product brand image will encourage potential buyers of the product to be compared with other brands with the same product.

Brand Image reflects consumer perceptions and evaluations related to a brand [19]. Companies compete to provide good ideas about their products and services to build a positive image of their brand in the minds of customers. So, a good perception of the quality of products and services will encourage customers to form a positive brand image [20]. Brand image is more about what consumers have in mind about a product. Consumers have their own image and perception of a brand which is the result of the brand association built by the company [21]. 
From the above definition, it can be concluded that Brand Image is a perception that exists in the minds of consumers which is formed from brand associations built by companies that will encourage consumers to compare with other brands.

\section{Electronic Word of Mouth and Brand Switching Relationship \\ In a traditional environment, when there are} negative words from message senders and recipients, there will be a stronger relationship between the intensity of information sent by negative WOM information to consumers about the brand which will have a major impact on brand switching. Whereas in an environment that is connected to the network in electronic form, negative messages have a significant impact on brand switching [22].

Research conducted by [23] on Oppo F9 products to Xiaomi Pocophone at RNY Communication Sukabumi City electronic word of mouth (eWOM) has a significant effect on brand switching. Delivering information through the web is able to make consumers who initially did not know the advantages and disadvantages of a product to know the weaknesses and strengths of the product. Based on the results of research on Mamypoko products in Jakarta by [24], it is known that involvement and eWOM partially and simultaneously affect brand switching behavior through brand image. Therefore, involvement, eWOM, and also brand image must be important variables that must be considered in order to prevent consumers from switching to other brands.

$\mathrm{H}_{1}$ : The higher the electronic word of mouth, the higher the brand switching rate

\section{Sales Promotion and Brand Switching Relationships}

A large part of the advertising process is aimed at encouraging brand switching among consumers. Convincing consumers to switch brands is sometimes a difficult task. It is not uncommon for consumers to build great brand loyalty because factors such as quality, price, and availability are met [25].

In a study conducted by [26] on the effect of sales promotion on brand switching on shampoo products in the city of Jammu Tawi, India, consumer sales promotion has a greater influence on brand switching compared to loyal consumers. In addition, among the various forms of sales promotion, free gifts have a greater influence on consumer brand switching behavior. Furthermore, it was found that economic status is not a factor that determines or influences brand consumer loyalty. Research conducted by [27] on telecommunications consumers in the city of Faisalabad, Pakistan that having a promotional tool is the most influential factor on customers. The results of decisions regarding brand switching show that most respondents change cellular service providers in response to changes in sales promotion.
$\mathrm{H}_{2}$ : The higher the sales promotion, the higher the level of brand switching

\section{Electronic Word of Mouth and Brand Image Relationship}

A study conducted by [28] recommends that marketers of lifestyle products in India should emphasize beneficial eWOM communication to increase brand image which will encourage customer purchase intentions. The results of a study conducted by [29] confirmed the significant effect of eWOM on purchase intention through brand image in consumers using smartphone brands. eWOM plays an important role in creating a brand image for companies and brands that can influence consumer purchase intentions.

But research conducted by [30] on the automotive industry in Malaysia shows that WOM communication has a greater impact than other communication media such as advertising, arguing that the information obtained from WOM communication is reliable. In addition, research also shows that only $14 \%$ of consumers believe what advertisements communicate.

$\mathrm{H}_{3}$ : The higher the electronic word of mouth, the higher the brand image level

\section{Sales Promotion Relationship and Brand Image}

Promotional activities, such as events, sponsorship, awareness campaigns, advertisements and public relations activities have a direct relationship and positive cognitive impact to some extent that adds brand value [31].

Frequent use of promotion affects consumer evaluation of brand image, but the effect depends on the type of promotional tool and product. Frequent use of price promotions will lower the value of the brand image whereas non-price promotions lead to higher brand evaluation [32].

The coefficient test results from simple linear regression analysis show that direct promotion has a significant effect on brand image at the AKN Putra Sang Fajar Blitar campus in a positive direction [33].

\section{$\mathrm{H}_{4}$ : The higher the sales promotion, the higher the brand image}

\section{The Relationship between Brand Image and Brand Switching}

One of the factors that can influence a consumer to make a brand shift is brand image. According to [34] brand image can be considered as a type of association that appears in the minds of consumers when remembering a particular brand. This association can simply appear in the form of thinking about a certain image associated with a brand, just as when we think about other people. 
A strong brand image can provide a special attraction for consumers; it cannot be denied that branded products always have a special space in the hearts of consumers. In fact, it is not uncommon for consumers to prefer to buy products that have wellknown brands rather than choosing new products whose identities are not clear. The stronger the brand image of a product, the greater the consumer's interest in buying the product, and the lower the tendency for brand to shift.

The results of research conducted by [35-37], show that brand image has a significant effect on brand switching.

$H_{5}$ : The higher the brand image, the higher the brand switching rate

\section{Relationship between Electronic Word of Mouth and Brand Switching through Brand Image}

In an era of increasingly rapid technology, companies must innovate more in marketing their products or services to consumers, one of which is electronic word of mouth (eWOM). eWOM is an online platform that companies use to offer products to consumers and as a means of communication between consumers and companies or consumers to consumers (public discussion). Through eWOM, companies can see whether or not they have a big influence on consumers about the products or services the company offers. With the interaction between companies and consumers, there is an increasingly strong relationship between the intensity of information sent by companies through eWOM to consumers about the company's product brands that have a major impact on brand switching.

Brand image also has a relationship with eWOM and brand switching, because a good brand image of the products offered will be able to influence consumer intentions to buy the products the company offers.

Based on the results of research on Mamypoko products in Jakarta by [38] it is known that eWOM affects brand switching through brand image. Therefore, the involvement of eWOM and brand image must be important variables that must be considered in order to prevent consumers from switching to other brands.

$H_{6}$ : The higher the brand image, the higher the relationship between electronic word of mouth and brand switching
Relationship between Sales Promotion and Brand Switching through Brand Image

Promotion has a positive and significant effect on brand switching [39]. This means that the better the promotion the company does, the more consumers will move from the previous product to the company's product. In increasing consumer brand switching, companies need to see the brand image of their products or services in the company. Where by doing sales promotion, consumers will evaluate the brands offered by the company. So it can be concluded that the brand image can also influence consumers to switch to a new brand if the sales promotion offered by the company is in accordance with the wishes of the consumers.

$\mathrm{H}_{7}$ : The higher the brand image, the higher the relationship between sales promotion and brand switching

\section{CONCEPTUAL FRAMEWORK} follows:

The conceptual framework in this study is as

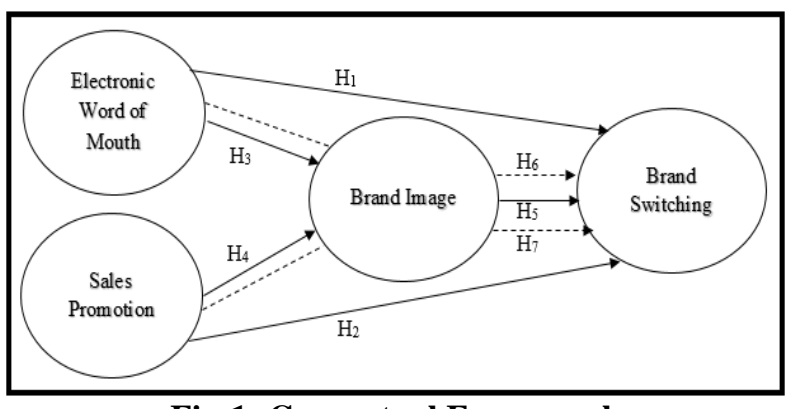

Fig-1: Conceptual Framework

\section{METHODOLOGY}

Types and Sources of Data

The exogenous variables in this study are electronic word of mouth (X1), sales promotion (X2). The intervening variable in this study is brand image (M) and the dependent variable is brand switching (Y). The population in this study were customers of the ERHA beauty clinic in Samarinda City and its surroundings. Because the exact number of population is not known, the number of samples is taken from a minimum of 5-10 times the number of indicators. The number of indicators in this study were 23 indicators, so the sample in this study was $5 \times 23$, namely 115 respondents who were deemed sufficient to represent the population.

\section{Variable Measurement}

The following are the indicators used in this study: 
Table-2: Research Variables

\begin{tabular}{|c|c|c|c|}
\hline No. & Variable & Author & Indicator \\
\hline 1. & $\begin{array}{l}\text { Electronic } \\
\text { Word of } \\
\text { Mouth }\left(\mathrm{X}_{1}\right)\end{array}$ & [40] & $\begin{array}{l}\text { Every day I read comments and news on social media. } \\
\text { I interact actively with social media users. } \\
\text { I like to read content on social media about prices and services of beauty clinics. } \\
\text { I read positive comments about ERHA beauty clinics on social media. } \\
\text { Social media users are often positive recommendations of ERHA clinics. } \\
\text { I read negative comments from social media about other Clinic. }\end{array}$ \\
\hline 2. & $\begin{array}{l}\text { Sales } \\
\text { Promotion } \\
\left(\mathrm{X}_{2}\right)\end{array}$ & [41] & $\begin{array}{l}\text { I have received discount coupons several times from ERHA clinics. } \\
\text { ERHA clinics often provide treatment packages at a lower price. } \\
\text { ERHA Clinic provides premium gifts for customers who purchase products and } \\
\text { services of a certain value. } \\
\text { Frequent visits to ERHA clinics will be rewarded. } \\
\text { ERHA Clinic provides free trials on special events. }\end{array}$ \\
\hline 3. & $\begin{array}{l}\text { Brand } \\
\text { Image }(\mathrm{M})\end{array}$ & [42] & $\begin{array}{l}\text { ERHA beauty clinic is a popular clinic. } \\
\text { ERHA beauty clinic has good credibility due to well-trained doctors and therapists. } \\
\text { ERHA beauty clinic has many branches in Indonesia. } \\
\text { ERHA beauty clinic has a good quality of service. } \\
\text { Doing treatment at ERHA beauty clinic increases my social status. } \\
\text { Doing skin care at the ERHA beauty clinic is one of my lifestyle. }\end{array}$ \\
\hline 4. & $\begin{array}{l}\text { Brand } \\
\text { Switching } \\
\text { (Y) }\end{array}$ & [43] & $\begin{array}{l}\text { I moved from another beauty clinic to ERHA beauty clinic because of the reasonable } \\
\text { price. } \\
\text { I moved from another beauty clinic to the ERHA beauty clinic because I was } \\
\text { satisfied with the quality of the products. } \\
\text { I moved from another beauty clinic to the ERHA beauty clinic for better service. } \\
\text { I moved from another beauty clinic to the ERHA beauty clinic because the place is } \\
\text { more comfortable and smells good. } \\
\text { I moved from another beauty clinic to the ERHA beauty clinic because it was easy to } \\
\text { place orders for its products. } \\
\text { I moved from another beauty clinic to an ERHA beauty clinic because I have no ties } \\
\text { with other clinics. }\end{array}$ \\
\hline
\end{tabular}

Source: Data processed, 2020

\section{RESULTS AND DISCUSSION \\ Outer Model Analysis Results}

The measurement analysis of this model was carried out through four stages of testing, namely individual item reliability, discriminant validity, average variance extracted (AVE) and internal consistency reliability:

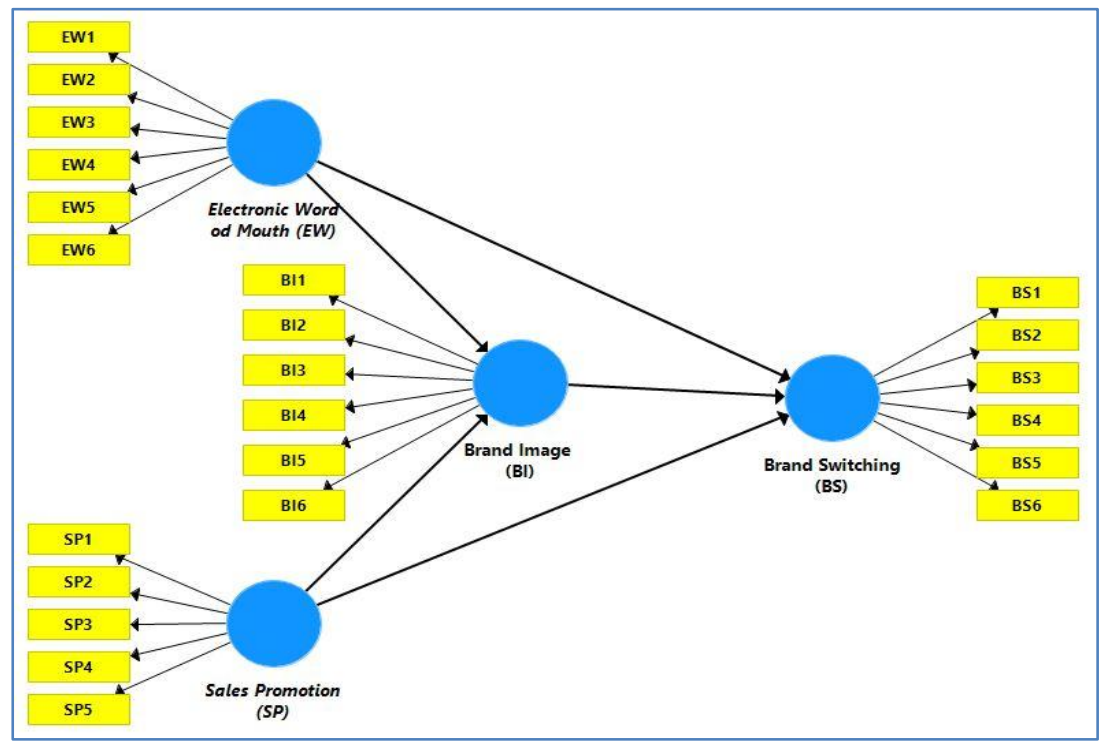

Fig-2: Structural Model 
Priskila Evalianitha Randabunga et al., Saudi J Bus Manag Stud, Apr, 2021; 6(4): 102-113

Figure 2 shows that the model used in this study consists of 4 constructs consisting of electronic word of mouth, sales promotion, brand image, and brand switching with as many as 23 question items.

\section{Validity test}

This test is done by looking at the standardized loading factor. Value describes the magnitude of the correlation between each indicator and its construct. The loading factor value that can be said is valid if it has a value greater than 0.7. However, there are several other researchers who say that if the loading factor value is greater than 0.5 , it means that the item is valid. Output SmarPLS 3 for loading factor gives the following results:

Table-3: Outer Loading Results

\begin{tabular}{|c|c|c|c|}
\hline Construct & Question indicator & Code & $\begin{array}{l}\text { Outer } \\
\text { Loadings } \\
\text { Results }\end{array}$ \\
\hline \multirow{6}{*}{$\begin{array}{l}\text { Electronic } \\
\text { Word of } \\
\text { Mouth } \\
\text { (EW) }\end{array}$} & Every day I read comments and news on social media. & EW.1 & 0.708 \\
\hline & I interact actively with social media users. & EW.2 & 0.735 \\
\hline & I like to read content on social media about prices and services of beauty clinics. & EW.3 & 0.738 \\
\hline & I read positive comments about ERHA beauty clinics on social media. & EW.4 & 0.719 \\
\hline & Social media users often provide positive ERHA clinic recommendations. & EW.5 & 0.720 \\
\hline & I read negative comments from social media about other Clinic. & EW.6 & 0.739 \\
\hline \multirow{5}{*}{$\begin{array}{l}\text { Sales } \\
\text { Promotion } \\
\text { (SP) }\end{array}$} & I have received discount coupons several times from the ERHA Clinic. & SP.1 & 0.747 \\
\hline & ERHA clinics often provide treatment packages at a lower price. & SP.2 & 0.787 \\
\hline & $\begin{array}{l}\text { ERHA Clinic provides premium gifts for customers who purchase products and } \\
\text { services of a certain value. }\end{array}$ & SP.3 & 0.809 \\
\hline & Frequent visits to the ERHA Clinic will be rewarded. & SP.4 & 0.766 \\
\hline & ERHA Clinic gives Free Trial on special events. & SP.5 & 0.767 \\
\hline \multirow{6}{*}{$\begin{array}{l}\text { Brand } \\
\text { Image } \\
\text { (BI) }\end{array}$} & ERHA beauty clinic is a popular clinic. & BI.1 & 0.748 \\
\hline & $\begin{array}{l}\text { ERHA beauty clinic has great credibility due to well-trained doctors and } \\
\text { therapists. }\end{array}$ & BI.2 & 0.746 \\
\hline & ERHA beauty clinic has many branches in Indonesia. & BI.3 & 0.780 \\
\hline & ERHA beauty clinic has a good quality of service. & BI.4 & 0.743 \\
\hline & Getting treatment at ERHA beauty clinic improves my social status. & BI.5 & 0.763 \\
\hline & Providing skin care at ERHA Clinic has become one of my lifestyle. & BI.6 & 0.761 \\
\hline \multirow{6}{*}{$\begin{array}{l}\text { Brand } \\
\text { Switching } \\
\text { (BS) }\end{array}$} & $\begin{array}{l}\text { I moved from another beauty clinic to ERHA beauty clinic because of the } \\
\text { reasonable price. }\end{array}$ & BS.1 & 0.784 \\
\hline & $\begin{array}{l}\text { I moved from another beauty clinic to the ERHA beauty clinic because I was } \\
\text { satisfied with the quality of the products. }\end{array}$ & BS.2 & 0.766 \\
\hline & $\begin{array}{l}\text { I moved from another beauty clinic to the ERHA beauty clinic because it provides } \\
\text { better service. }\end{array}$ & BS.3 & 0.771 \\
\hline & $\begin{array}{l}\text { I moved from another beauty clinic to the ERHA beauty clinic because the place } \\
\text { is more comfortable and smells good. }\end{array}$ & BS.4 & 0.751 \\
\hline & $\begin{array}{l}\text { I moved from another beauty clinic to the ERHA beauty clinic because it was } \\
\text { easy to order products. }\end{array}$ & BS.5 & 0.751 \\
\hline & $\begin{array}{l}\text { I moved from another beauty clinic to the ERHA beauty clinic because I have no } \\
\text { ties with other clinics. }\end{array}$ & BS.6 & 0.793 \\
\hline
\end{tabular}

Source: Data processed, 2020 (SmartPLS 3)

After testing in this study, all question items in this study had a value above 0.7 , meaning that all question indicators used in this study were valid or had met convergent validity.
The following are the loading factor diagram values for each indicator in the research model: 


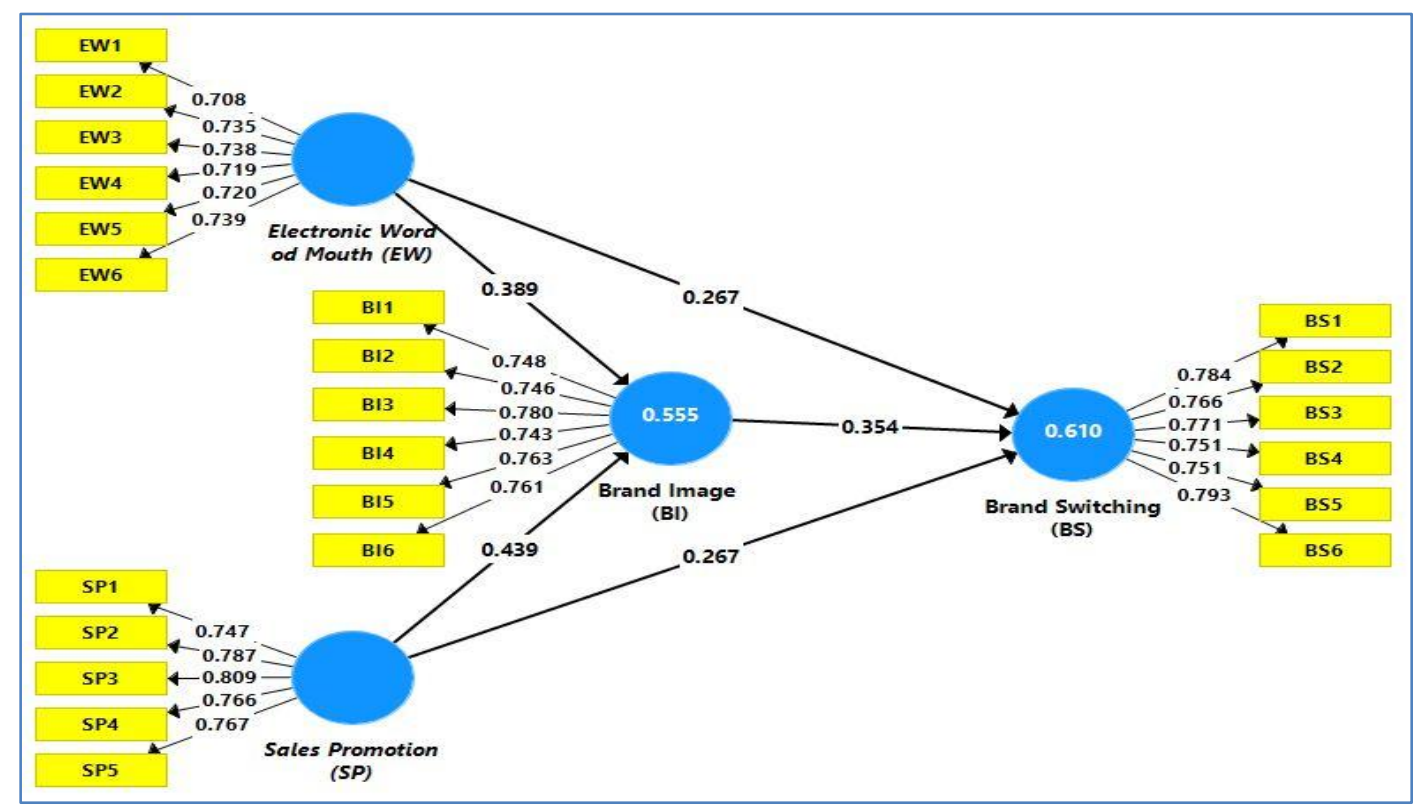

Fig-3: Loading Factor Result Value

\section{Cross Loading Test}

In this study, the cross loading value for each indicator has met the existing requirements so that it can be used for this study. The value of cross loading between indicators can be seen in table-4:

Table-4: Cross Loadings Results

\begin{tabular}{|c|c|c|c|c|c|}
\hline \multirow[b]{2}{*}{ Construct } & \multirow[b]{2}{*}{ Code } & \multicolumn{4}{|c|}{ Results of Cross Loadings } \\
\hline & & $\begin{array}{l}\text { Electronic Word } \\
\text { Of Mouth (EW) }\end{array}$ & $\begin{array}{ll}\text { Sales } & \text { Promotion } \\
\text { (SP) }\end{array}$ & $\begin{array}{ll}\begin{array}{l}\text { Brand } \\
\text { (BI) }\end{array} & \text { Image } \\
\end{array}$ & $\begin{array}{l}\text { Brand } \\
\text { Switching (BS) }\end{array}$ \\
\hline \multirow{6}{*}{ EW } & EW.1 & 0.708 & 0.516 & 0.515 & 0.517 \\
\hline & EW.2 & 0.735 & 0.438 & 0.500 & 0.476 \\
\hline & EW.3 & $\begin{array}{l}0.738 \\
\end{array}$ & 0.428 & 0.471 & 0.513 \\
\hline & EW.4 & 0.719 & 0.387 & 0.486 & 0.460 \\
\hline & EW.5 & 0.720 & 0.477 & 0.501 & 0.411 \\
\hline & EW.6 & 0.739 & 0.447 & 0.399 & 0.522 \\
\hline \multirow{5}{*}{ SP } & SP.1 & 0.466 & 0.747 & 0.507 & 0.557 \\
\hline & SP.2 & 0.442 & 0.787 & 0.500 & 0.517 \\
\hline & $\begin{array}{l}\text { SP.3 } \\
\end{array}$ & 0.522 & 0.809 & 0.556 & 0.496 \\
\hline & SP.4 & 0.492 & 0.766 & 0.557 & 0.552 \\
\hline & SP.5 & 0.473 & 0.767 & 0.511 & 0.483 \\
\hline \multirow{6}{*}{ BI } & BI.1 & 0.443 & 0.501 & 0.748 & 0.530 \\
\hline & BI.2 & 0.476 & 0.520 & 0.746 & 0.556 \\
\hline & BI.3 & 0.416 & 0.483 & 0.780 & 0.499 \\
\hline & BI.4 & 0.421 & 0.469 & 0.743 & 0.458 \\
\hline & BI.5 & 0.612 & 0.532 & 0.763 & 0.550 \\
\hline & BI.6 & 0.590 & 0.564 & 0.761 & 0.616 \\
\hline \multirow{6}{*}{ BS } & BS.1 & 0.547 & 0.532 & 0.596 & 0.784 \\
\hline & BS.2 & 0.524 & 0.555 & 0.550 & 0.766 \\
\hline & BS.3 & 0.519 & 0.535 & 0.576 & 0.771 \\
\hline & BS.4 & 0.470 & 0.450 & 0.506 & 0.751 \\
\hline & BS.5 & 0.496 & 0.467 & 0.517 & 0.751 \\
\hline & BS.6 & 0.516 & 0.559 & 0.538 & 0.793 \\
\hline
\end{tabular}

Source: Data processed, 2020 (SmartPLS 3)

The average variance extracted (AVE) value is used to describe the amount of variance or diversity of indicators that exist in the latent construct. A good AVE value is more or above 0.5. AVE value for each construct can be seen in table-5: 
Table-5: Average Variance Extracted Results

\begin{tabular}{|l|l|}
\hline Construct & Average Variance Extracted (AVE) Results \\
\hline Electronic Word Of Mouth (EW) & 0.528 \\
\hline Sales Promotion (SP) & 0.602 \\
\hline Brand Image (BI) & 0.573 \\
\hline Brand Switching (BS) & 0.592 \\
\hline
\end{tabular}

Source: Data processed, 2020 (SmartPLS 3)

In this study, the AVE values for all constructs were above 0.5 so that all constructs could be used in this study.

\section{Reliability Test}

This test is done by looking at the composite reliability and Cronbach's alpha value with a threshold of 0.7. the results of the reliability test in this study can be seen in table- 6 below:

Table-6: Reliability Test

\begin{tabular}{|l|l|l|l|}
\hline Variable & $\begin{array}{l}\text { Composite Reliability } \\
(>\mathbf{0 , 7 0})\end{array}$ & $\begin{array}{l}\text { Cronbach Alpha } \\
(>\mathbf{0 , 6 0 )}\end{array}$ & Information \\
\hline EW & 0.870 & 0.821 & Reliable \\
\hline SP & 0.883 & 0.834 & Reliable \\
\hline BI & 0.889 & 0.851 & Reliable \\
\hline BS & 0.897 & 0.862 & Reliable \\
\hline EW & 0.870 & 0.821 & Reliable \\
\hline
\end{tabular}

Source: Data processed, 2020 (SmartPLS 3)

From table- 6 above, it can be concluded that the four constructs used in this study are reliable so that this model can be continued for further analysis, namely the inner model.

\section{Inner Model Testing}

This test is done to see and measure how much the dependent latent construct has the influence relationship described by the independent latent construct. The following is the $\mathrm{R} 2$ value for the two independent constructs in this study:

Table-7: Results of the Coefficient of Determination

\begin{tabular}{|c|c|c|}
\hline Dependent construct & $\mathbf{R}^{2}$ & Analysis \\
\hline Brand Image (BI) & 0.555 & Moderate \\
\hline Brand Switching (BS) & 0.610 & Moderate \\
\hline
\end{tabular}

In table-7, the highest $\mathrm{R} 2$ value is the value for brand switching, which is 0.610 , which means that the construct of electronic word of mouth, sales promotion, and brand image explains the overall variant of the brand switching construct in a moderate (moderate) manner at $61 \%$ while the rest is $39 \%$ described outside the research construct.

Furthermore, the value of R2 for brand image is 0.555 which means that the construct of electronic word of mouth, sales promotion, and brand image explains the overall variant of the brand image construct in a moderate (moderate) amount of $55.5 \%$ while the remaining $44.5 \%$ is explained outside the research construct.

\section{Hypothesis testing}

Hypothesis testing is carried out using the bootstrapping method with a two-tailed test with a significance level of 5\% to test the research hypothesis. The hypothesis is accepted if the value of the t-test is greater than 1.96. The following are the results of hypothesis testing in this study: 
Priskila Evalianitha Randabunga et al., Saudi J Bus Manag Stud, Apr, 2021; 6(4): 102-113

Table-8: Hypothesis Test

\begin{tabular}{|l|l|l|l|l|l|}
\hline No & Construct & Estimate & t-test & p-value & Information \\
\hline Direct Effects & $(\mathrm{EW}) \rightarrow(\mathrm{BS})$ & 0.267 & 2.935 & 0.004 & Received \\
\hline 1 & $(\mathrm{SP}) \rightarrow(\mathrm{BS})$ & 0.267 & 3.638 & 0.000 & Received \\
\hline 2 & 0.389 & 5.598 & 0.000 & Received \\
\hline 3 & $(\mathrm{EW}) \rightarrow(\mathrm{BI})$ & 0.439 & 6.624 & 0.000 & Received \\
\hline 4 & $(\mathrm{SP}) \rightarrow(\mathrm{BI})$ & 0.354 & 3.331 & 0.001 & Received \\
\hline 5 & $(\mathrm{BI}) \rightarrow(\mathrm{BS})$ & \multicolumn{5}{|l|}{} \\
\hline Indirect Effects & $(\mathrm{EW}) \rightarrow(\mathrm{BI}) \rightarrow(\mathrm{BS})$ & 0.138 & 2.839 & 0.005 & Received \\
\hline 6 & $(\mathrm{SP}) \rightarrow(\mathrm{BI}) \rightarrow(\mathrm{BS})$ & 0.156 & 2.795 & 0,006 & Received \\
\hline 7 &
\end{tabular}

Source: Data processed, 2020 (SmartPLS 3)

Based on table-8, it can be seen that the results of hypothesis testing in this study are that the effect of electronic word of mouth with brand switching is significant with a t-test of $(2,935>1.96)$. The original sample estimate value is positive, namely 0.267 which indicates that the direction of the relationship is unidirectional. The effect of sales promotion with brand switching is significant with a t-test of $(3,638>1,96)$. The original sample estimate value is positive, namely 0.267 which indicates that the direction of the relationship is unidirectional.

The effect of electronic word of mouth with brand image is significant with a t-test of $(5,598>1.96)$. The original sample estimate value is positive which is equal to 0.389 which indicates that the direction of the relationship is unidirectional.

The effect of sales promotion with brand image is significant with a t-test of (6.624>1.96). The original sample estimate value is positive, which is 0.439 which indicates that the direction of the relationship is unidirectional.
The effect of brand image with brand switching is significant with a t-test of (3.331> 1.96). the original sample estimate value is positive which is equal to 0.354 which indicates that the direction of the relationship is unidirectional.

The influence of electronic word of mouth with brand switching through brand image is significant with a t-test of $(2.839>1.96)$. The original sample estimate value is positive, which is 0.138 which indicates that the direction of the relationship between electronic word of mouth and brand switching through brand image is unidirectional.

The effect of sales promotion with brand switching through brand image is significant with a ttest of $(2,795>1,96)$. The original sample estimate value is positive, namely 0.156 which indicates that the direction of the sales promotion relationship to brand switching through brand image is unidirectional.

To see the output in the form of a diagram with a t-test value using SmartPLS 3, it can be seen as follows:

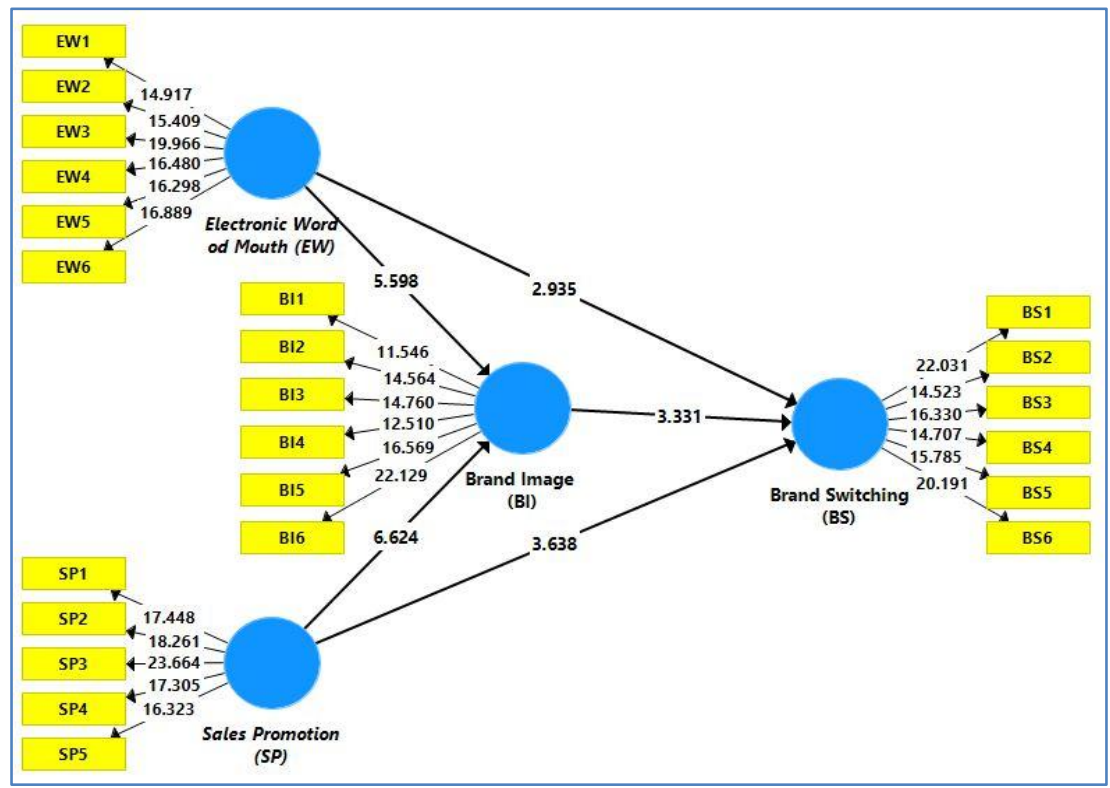

Fig-4: T-Test Value of Bootstrapping Output Results 
Priskila Evalianitha Randabunga et al., Saudi J Bus Manag Stud, Apr, 2021; 6(4): 102-113

\section{CONCLUSIONS AND SUGGESTIONS}

Based on the results of the analysis that has been stated, it can be concluded that electronic word of mouth has a positive and significant effect on brand switching, which means that the higher the electronic word of mouth that occurs or is carried out by consumers, the opportunity for brand switching to the ERHA Beauty Clinic. In Kota Samarinda will happen.

Sales Promotion has a positive direction towards Brand Switching and has a significant effect; this shows that if the ERHA Beauty Clinic focuses on promoting sales, of course the potential or opportunity for consumers to do Brand Switching.

Electronic Word Of Mouth has a positive direction and has a significant influence on Brand Image, so if the higher the Electronic Word Of Mouth carried out by consumers, the better the brand image at ERHA Beauty Clinic in Samarinda City. Of course this will have a positive impact on ERHA Beauty Clinic so that consumers will be more loyal.

Sales Promotion has a positive direction and has a significant influence on Brand Image, the better the sales promotion carried out by the ERHA Beauty Clinic in Samarinda City, it will certainly make the brand image more positive, of course it will make ERHA Beauty Clinic customers in Samarinda City more comfortable and satisfied.

Brand image has a positive direction and has a significant influence on Brand Switching; of course this is because the brand image that has been built by ERHA Beauty Clinic in Samarinda City is very good for customers so that it will influence consumer behavior to switch from other beauty clinics to ERHA Beauty Clinics in Samarinda City.

Electronic Word Of Mouth on Brand Switching through Brand Image is significant and shows a positive direction. Thus in research the effect of Electronic Word of Mouth and Sales Promotion on Brand Switching with Brand Image As an intervening variable at the ERHA Beauty Clinic in Samarinda, which states that "Electronic Word of Mouth has an indirect effect on brand switching through Brand Image. will make the ERHA Beauty Clinic in Samarinda City have good potential in continuing to develop innovations to make consumers more loyal.

The results show that the relationship between Sales Promotion and Brand Switching through Brand Image is significant and the direction shows a positive direction, thus in the research the effect of Electronic Word of Mouth and Sales Promotion on Brand Switching with Brand Image as an intervening variable at the ERHA Beauty Clinic in Samarinda City. Which states that "Sales Promotion has an indirect effect on brand switching through Brand Image. This is interesting because in the desire of consumer behavior towards brand switching to another beauty clinic, it will be canceled with the brand image that has been built by the ERHA Beauty Clinic in Samarinda City, so that customers will continue to be loyal customers at the ERHA Beauty Clinic, therefore it is necessary to do an evaluation. and ensure that customer satisfaction will be maintained so as not to move to another place.

Based on the results of the analysis that has been concluded, some suggestions that can be given based on the results of this study are the ERHA Beauty Clinic in Samarinda City can conduct polls with customers on service quality and how the brand image that customers want in the future with many other beauty clinics, clinics ERHA is able to keep customers from doing brand switching wishes at other beauty clinics.

ERHA Beauty Clinic in Samarinda City should always pay attention and evaluate how the brand image to be always good in the minds of customers, because this is very dangerous if customers start to be dissatisfied with the brand image that is built will have an impact on the Electronic Word Of Mouth which will be created by the customer himself, so that the chances of moving to another clinic will be even greater.

ERHA Beauty Clinic in Samarinda City needs to innovate in Sales Promotion so that there is a sense of desire and interest felt by customers, this will certainly help ERHA Beauty Clinic customers in Samarinda City, always curious and want to know what form and Sales Promotion will be offered. by ERHA Beauty Clinic in Samarinda City.

In further research, it is expected that those with similarities from the variables, to add more other variables, so that you will find something interesting in similar research, then the object selection can be expanded again so that it will produce new findings from the point of view of other objects. Then the research subject can be added later, not only from the customer side, maybe it can be developed from the point of view of other objects such as subjects who are customers at other beauty clinics.

Recommend to the next researchers that they can take samples from several cities, so that they can measure how the location, culture and lifestyle in different cities are found, so that different results can be found, so that they can be new findings and can be helpful for researchers who will research with the same title or variable.

\section{REFERENCE}

1. Wong, K. H., Chang, H. H., \& Yeh, C. H. (2019). The effects of consumption values and relational benefits on smartphone brand 
switching behavior. Information Technology \& People.

2. Pasaribu, R., \& Sugiarto, A. (2011). 'Pengaruh E-WOM Terhadap Peralihan Merek Dengan Citra Merek Sebagai Variabel Mediasi', Economics and Business, 16(110), 853-862.

3. Daugherty, T., \& Hoffman, E. (2014). 'eWOM and the importance of capturing consumer attention within social media', Journal of Marketing Communications. Taylor \& Francis, 82-102.

4. Mohammed, A., \& Ilkan, M. (2016). 'Journal of Destination Marketing \& Management Impact of online WOM on destination trust and intention to travel: A medical tourism perspective', Journal of Destination Marketing \& Management. Elsevier, 1-10.

5. Eleboda, S. S. (2017) .'Sales Promotion as a Strategy in Service Marketing: Exploring the Believability Dilemma and Consumer Purchase Decision', American Journal of Marketing Research, 3(2), 8-15.

6. Woisetschläger, D. M., \& Michaelis, M. (2012). 'Sponsorship congruence andbrand image', European Journal of Marketing, 46(3).

7. Pookulangara, S. A., Hawley, J., \& Xiao, G. (2011). 'Explaining consumers' channelswitching behavior using the theory of planned behavior', Journal of Retailing and Consumer Services, 18(4), 311-321.

8. Gupta, R. (2017). 'Promotion Mix And Brand Switching Behaviour: A Synthesis Of Evidences, Measurement And Moderating Variables.', ELK Asia Pacific Journal Of Marketing and Retaill Management, 8(4).

9. Nagarajan, S., \& Jafersadhiq, A. (2019). 'A Research on Brand Switching Factors of Millennial Customers on Toiletries', (12), 490494.

10. Yang, F. X. (2013). 'Effects of Restaurant Satisfaction and Knowledge Sharing Motivation on eWOM Intentions: The Moderating Role of Technology Acceptance Factors', Journal of Hospitality \& Tourism Research, 20(10).

11. Cheung, C. M. K., \& Thadani, D. R. (2012). 'The impact of electronic word-of-mouth communication: A literature analysis and integrative model', Decision Support Systems. Elsevier B.V., 54(1), 461-470.

12. Arif, M. E. (2019). 'The Influence of Electronic Word of Mouth (Ewom), Brand Image, and Price on Re-Purchase Intention of Airline Customers', Jurnal Aplikasi Manajemen, 17(2), 345-356.

13. Jean, W. A., \&Yazdanifard, R. (2015). 'The Review of how Sales Promotion Change the Consumer's Perception and Their Purchasing Behavior of a Product The Review of how Sal es Promotion Change the Consumer's Perception and Their Purchasing Behavior of a Product',
Global Journal of Management and Business Research, 15(5), 32-37.

14. Keyan, B. K., \& Natarajan, P. (2019). 'Impact of Sales Promotion Techniques on Consumers towards FMCG Impact of Sales Promotion Techniques on Consumers towards FMCG', International Research Journal of Business and Management - IRJBM, 5(March). Available at: https://www.researchgate.net/publication/331787 104_Impact_of_Sales_Promotion_Techniques_o n_Consumers_towards_FMCG.

15. Chang, A. Y. (2017). 'A Study on the Effects of Sales Promotion on Consumer Involvement and Purchase Intention in Tourism Industry', 8223(12), 8323-8330.

16. Sinha, S. K., \& Priyanka, V. (2018). 'Impact of Sales Promotion' $s$ Benefits on Brand Equity: An Empirical Investigation', Global Business Review, 19(6), 1-18.

17. Kotler, P., \& Keller, K. L. (2012). Marketing Management. 14th edn. Edited by S. Yagan. New Jersey: Prentice Hall.

18. Sjafar, O., \& Djamaluddin, S. (2017). 'The Effect of Brand Image , Product Quality , and Relationship Marketing on Customer Satisfaction and Loyalty', 2(10), 15-24.

19. Anselmsson, J., Bondesson, N. V., \& Johansson, U. (1993). 'Brand image and customers ' willingness to pay a price premium for food brands'.

20. Sallam, M. A. (2014). 'The Effects of Brand Image and Brand Identification on Brand Love and Purchase Decision Making: The Role of WOM', 7(10), 187-193.

21. Halim, P. (2014). 'The Influence of Product Quality, Brand Image , and Quality of Service to Customer Trust and Implication on Customer Loyalty ( Survey on Customer Brand Sharp Electronics Product at the South Kalimantan Province )', 6(29), 159-166.

22. Xiaoping, L., \& Pinghua, F. (2010). 'Study on the Effects of the Negative WOM on Brand Switching in the net Environment'.

23. Pirdaus, A., Danial, R. D. M., \& Ramdan, A. M. (2020). 'Analisis Efek Komunitas dan Electronic Word of Mouth Terhadap Brand Switching Produk XIAOMI POCOPHONE ke OPPO F9 Di RNY Communication Kota Sukabumi', Journal of Management and Bussines (JOMB), 2(1).

24. Gunawan, A. (2016). 'The effect of involvement and electronic word of mouth (eWOM) on brand image and its impact on consumers brand switching of mamypoko', International Journal of Economics and Management, 10(Speciallssue1), 19-31.

25. Rajkumar, R., \& Chaarlas, L. (2011). 'Brand Switching in Cellular Phone Service Industry Because of Bill - Related Issues Faced by Clients', Ijemr, 1(5), 2249-2585. Available at: http://www.exclusivemba.com/ijemr. 
Priskila Evalianitha Randabunga et al., Saudi J Bus Manag Stud, Apr, 2021; 6(4): 102-113

26. Nagar, K. (2009). 'Evaluating the Effect of Consumer Sales Promotions on Brand Loyal and Brand Switching Segments', Vision: The Journal of Business Perspective, 13(4), 35-48.

27. Khasanah, U., \& Cahya, B. T. (2018). 'Brand Switching Produk Kosmetik Halal: Ditinjau dari Aspek Daya Tarik Iklan dan Variety Seeking', AKTSAR: Jurnal Akuntansi Syariah, 1(2), 199.

28. Kala, D., \& Chaubey, D. S. (2018). 'The effect of eWOM communication on brand image and purchase intention towards lifestyle products in India', 9(2), 143-157.

29. Alrwashdeh, M., Emeagwali, O. L., \& Aljuhmani, H. Y. (2019). 'The effect of electronic word of mouth communication on purchase intention and brand image: An applicant smartphone brands in north Cyprus', Management Science Letters, 9(4), 505-518.

30. Al Halbusi, H., \& Tehseen, S. (2018). 'The Effect of Electronic Word-Of-Mouth (EWOM) On Brand Image and Purchase Intention: A Conceptual Paper', SocioEconomic Challenges, 2(3), 83-94.

31. Al Saed, R., Upadhya, A., \& Abu Saleh, M. (2020). 'Role of airline promotion activities in destination branding: Case of Dubai vis-à-vis Emirates Airline', European Research on Management and Business Economics. The Author(s), 26(3), 121-126.

32. Montaner, T., \& Pina, J. M. (2008). 'The effect of promotion type and benefit congruency on brand image', Journal of Applied Business Research, 24(3), 15-28.

33. Wardani, S. I., Latifah, N., \& Rachmawati, I. (2020). 'Efektivitas Direct Promotion Terhadap Brand Image (Studi Kasus Pada Akademi Komunitas-Negeri- Putra-Sang-Fajar-Blitar)', Briliant: Jurnal Riset dan Konseptual, 5(1), 51.

34. Rohman, Y. S. (2016). 'Pengaruh Ketidakpuasan Konsumen, Kualitas Produk, Merek Desain, dan Fitur Produk Terhadap Keputusan Perpindahan Merek Smartphone Android ke Apple Iphone', Skripsi Universitas Lampung.

35. Chigwende, S., \& Govender, K. (2020). 'Corporate brand image and switching behavior:
Case of mobile telecommunications customers in Zimbabwe', Innovative Marketing, 16(2), 80-90.

36. Pelupessy, S. J., Wardana, M., \& Suprapti, N. W. S. (2017). 'Peran Brand Image Dalam Memediasi Pengaruh Wom Terhadap Switching Intention Ke Produk Smartphone Merek Samsung Di Denpasar', Jurnal Ekonomi dan Bisnis Universitas Udayana, 6(5), 1939-1966.

37. Cahyono, A. (2015). 'The Influence of Brand Image, Price and Promotion on Brand Switching (Survey on Student of Business Administration Faculty of Administrative Science Brawijaya University Who Had Ever Switched to Other SIM Card Providers)', Jurnal Administrasi Bisnis (JAB) Universitas Brawijaya, 18(1).

38. Gunawan, A. (2016). 'The effect of involvement and electronic word of mouth (eWOM) on brand image and its impact on consumers brand switching of mamypoko', International Journal of Economics and Management, 10(SpecialIssue1), 19-31.

39. Sari, D. M. F. P., \& Dewi, D. A. P. Y. T. (2020). 'Brand Switching Smartphone (Xiaomi dan Oppo) Pada Erafone Megastore di Kota Denpasar', Jurnal Ilmiah Manajemen dan Bisnis, 2(2), 89.

40. Goyette, I., Ricard, L., \& Bergeron, J. (2010). 'eWOM Scale: Word-of-Mouth Measurement Scale for e-Services Context*', Canadian Journal of Administrative Sciences, 27, 5-23.

41. Kotler, P., \& Keller, K. L. (2012). Marketing Management. 14th edn. Edited by S. Yagan. New Jersey: Prentice Hall.

42. Li, X. G., Wang, X., \& Cai, Y. J. (2011). 'Corporate-, product-, and user-image dimensions and purchase intentions: The mediating role of cognitive and affective attitudes', Journal of Computers, 6(9), 18751879.

43. Nadarajan, G., Bojei, J., \& Khalid, H. (2017). 'The study on negative eWOM and its relationship to consumer's intention to switch Mobile Service Provider', Procedia Computer Science. Elsevier B.V., 124, 388-396. 